\title{
Etno-Agronomi Budidaya Kopi yang Toleran Variabilitas Curah Hujan
}

\section{(Ethno-Agronomy of Coffee Growing with Tolerance to Rainfall Variability)}

\author{
Rusdi Evizal $^{1{ }^{* *}}$, Fembriarti Erry Prasmatiwi ${ }^{2)}$, Setyo Widagdo ${ }^{1)}$, Hery Novpriansyah ${ }^{3)}$ \\ 1) Jurusan Agroteknologi Fakultas Pertanian Universitas Lampung, Jl. Prof. Dr. Sumantri \\ Brojonegoro No. 1, Bandar Lampung, 35145, 2) Jurusan Agribisnis Fakultas Pertanian Universitas \\ Lampung, Jl. Prof. Dr. Sumantri Brojonegoro No. 1, Bandar Lampung, 35145, ${ }^{3)}$ Jurusan Ilmu Tanah \\ Fakultas Pertanian Universitas Lampung, Jl. Prof. Dr. Sumantri Brojonegoro No. 1, Bandar \\ Lampung, 35145 \\ E-mail:rusdi.evizal@fp.unila.ac.id
}

\begin{abstract}
West Lampung Regency still survives as the central area of coffee production in Lampung Province while production of other districts so far are declining. This research aims to study the ethno-agronomy of coffee cultivation in West Lampung which is tolerant to rainfall variability. This research was a survey located in Sumberjaya District and Sekincau District, West Lampung Regency, Lampung Province, Indonesia year 2018-2019 which from each subdistrict two villages was selected purposively and from each village one farmer group was chosen. Primary data were collected through interview, Focused Group Discussion $(F G D)$, and observation of coffee farm. Secondary data were obtained from the BPS Lampung and rainfall data from Radin Intan Climate Station. The results showed that the area of coffee plantations in West Lampung in the last decade has decreased by 0,64\% per year but productivity has increased by 1,42\% per year, and in West Lampung, which is a mountainous region, the number of rainy days was negatively correlated with coffee yield while the number of dry months was positively correlated. Whereas in North Lampung, which is a medium elevation area, coffee productivity correlated with sufficient rainfall and productivity was negatively correlated with the number of dry months of the previous year. Coffee farmers in West Lampung have perception the need for various adaptation measures of coffee farm maintenance, which grafting adult coffee tree with superior local robusta clones is a typical ethno-agronomy practiced by coffee farmers in West Lampung to obtain high coffee yield.
\end{abstract}

Keywords: adaptation, climate, coffee, etnoagronomy

DOI: http://dx.doi.org/10.25181/jaip.v8i1.1392

Diterima: 19 Oktober 2019 / Disetujui: 28 Maret 2020 / Diterbitkan: 16 Mei 2020

\section{PENDAHULUAN}

Kabupaten Lampung Barat mampu bertahan sebagai sentra utama penghasil kopi di Lampung meskipun menghadapi gejala perubahan iklim (Evizal et al., 2019). Menurut Panhuysen and Pierrot (2014) kopi termasuk tanaman yang rentan terhadap gejala perubahan iklim yang ditandai antara lain dengan kenaikan temperatur udara dan meningkatnya variabilitas dan ketidak-menentuan baik berupa bulan kering yang panjang, intensitas hujan yang tinggi, serta meningkatkan keterjadian 
dan kedahsyatan cuaca ekstrim yang menurunkan produksi kopi. Evizal et al. (2019) melaporkan bahwa saat ini hanya Kabupaten Lampung Barat yang masih sebagai sentra terluas perkebunan kopi robusta Lampung, sedangkan Kabupaten Tanggamus, Pesisir Barat, Lampung Selatan, Lampung Utara dan Kabupaten Way Kanan luas areal semakin menurun. Penurunan luas areal ini diduga diakibatkan beberapa faktor seperti perubahan iklim (Meza, 2014), meningkatnya harga komoditas lain seperti kakao (Evizal et al., 2018) dan kesesuaian lahan yang semakin menurun sehingga produksi menurun sementara biaya pengelolaan meningkat (Davis et al., 2012) misalnya meningkatnya biaya pengendalian gulma, pengendalian hama dan penyakit serta biaya pemangkasan.

Produktivitas kopi robusta bersifat berseling antara panen besar diikuti panen kecil. Menurut Reidsma et al. (2010) dalam kaitannya dengan perubahan iklim, produksi aktual berkorelasi tinggi dengan produksi pada keadaan air yang terbatas. Menurut Alemu and Dufera (2017) perubahan iklim meningkatkan risiko dalam usahatani kopi sehingga memerlukan upaya keras dalam pengembangan agroteknologi untuk meningkatkan pertanaman dan keberlanjutan budidaya kopi.

Perubahan iklm berpengaruh buruk terhadap produktivias kopi akibat peningkatan ekstrimitas curah hujan baik kekeringan maupun kelebihan air (Ovalle-Rivera et al., 2015). Variabilitas produksi kopi dapat ditekan dengan melakukan optimasi pengelolaan kebun seperti pengelolaan pohon naungan, kesuburan tanah, limbah tanaman, hama dan penyakit, perbaikan varietas dan diversifikasi dengan tanaman lain (Baca et al., 2014).

\section{METODE PENELITIAN}

Penelitian ini dilakukan secara survei yang berlokasi di Kecamatan Sumberjaya dan Kecamatan Sekincau Kabupaten Lampung Barat, Propinsi Lampung (Gambar 1). Dari masing-masing kecamatan dipilih secara purposif 2 desa sentra produksi kopi dan dari setiap desa dipilih satu kelompok tani. Data primer dikumpulkan melalui metode wawancara, Focused Group Discussion (FGD), dan observasi kebun yang terbaik dari anggota kelompok. Data sekunder perkebunan kopi diperoleh dari BPS Propinsi Lampung dan data curah hujan dari data Stasiun Pengamatan Iklim Radin Intan. Data dianalisis secara deskriptif dan dilakukan analisis korelasi - regresi antara variabel curah hujan dan produksi kopi Lampung Barat pada periode 2010-2017.

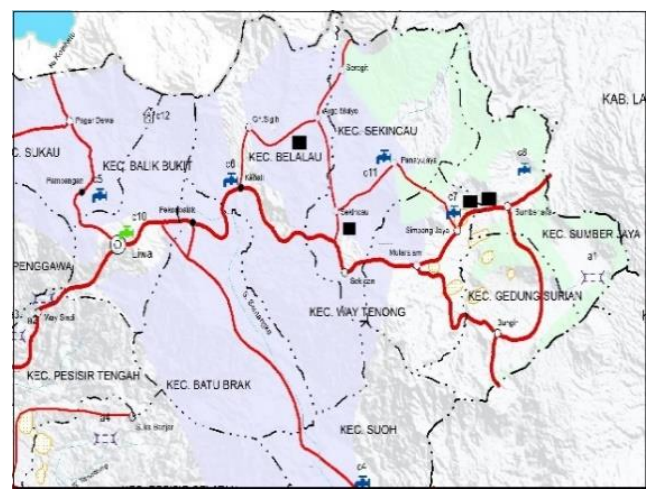

Gambar 1. Lokasi survei, bertanda kotak hitam (Sumber: loketpeta.pu.go.id) 


\section{HASIL DAN PEMBAHASAN}

\section{Kinerja Produksi}

Kinerja produksi kopi Lampung dalam satu dekade terakhir menunjukkan karakteristik yang berbeda antarkabupaten. Dari 3 kabupaten sentra utama, luas areal kopi di Kabupaten Lampung Barat dan Kabupaten Tanggamus menurun sedangkan di Kabupaten Lampung Utara meningkat. Pertumbuhan produksi kopi di Lampung Barat masih positif sedangkan di Kabupaten Tanggamus dan Lampung Utara pertumbuhan produksi kopi negatif terutama produksi kopi Lampung Utara yang menurun 2,4\% per tahun dengan pertumbuhan produktivitas yang turun 5,9\% per tahun (Tabel 1).

Kabupaten Lampung Barat masih bertahan sebagai sentra utama produksi kopi Lampung, meskipun luas areal sedikit menunjukkan penurunan namun produktivitas masih naik $1,4 \%$ per tahun. Peningkatan produktivitas menyebabkan peningkatan produksi meskipun areal menurun yaitu melalui intensifikasi dan perbaikan agroteknologi terutama penyambungan dengan klon unggul dan praktek pemeliharaaan. Lampung Barat dikenal memiliki banyak klon lokal unggul (Evizal, 2013; Evizal et al., 2015) yang sebagian sudah dilepas sebagai klon unggul nasional.

Petani melakukan adopsi melalui teknologi penyambungan untuk klonisasi pertanaman kopi yang sudah ada dan seleksi mandiri dari klon hasil persilangan alami melalui perbanyakan dengan biji atau hasil introduksi klon yang mampu beradaptasi dengan agroklimat lokal. Penyambungan kopi dengan klon lokal unggul mulai banyak dilakukan di Lampung mulai sekitar tahun 1990-an dan pada tahun 2000 sampai saat ini intensitas klonisasi sudah mendekati 100\% yang umumnya dilakukan secara bertahap (Evizal et al., 2010).

Tabel 1. Kinerja produksi kopi di tiga kabupaten pada 2006-2017

\begin{tabular}{lllll}
\hline No. & Peubah & Lampung Barat & Tanggamus & $\begin{array}{l}\text { Lampung } \\
\text { Utara }\end{array}$ \\
\hline 1. & Luas areal (ha) & & 18.668 \\
2. & Produksi (ton) & 58.685 & 47.241 & 11.628 \\
3. & Produktivitas (ton/ha) & 57.581 & 37.745 & 0,65 \\
4. & Pertumbuhan luas per tahun (\%) & 0,98 & 0,79 & 4,44 \\
5. & Pertumbuhan produksi per tahun (\%) & $-0,64$ & $-2,08$ & $-2,36$ \\
6. & Pertumbuhan produktivitas per tahun (\%) & 1,42 & -1.46 & $-5,90$ \\
\hline
\end{tabular}

Sumber: Analisis data

Pada satu dekade terakhir, produksi kopi di 2 kabupaten di Lampung bertumbuh negatif (Tabel 1). Menurut Syakir dan Surmaini (2017) produksi kopi rentan terhadap perubahan iklim. Kejadian cuaca ekstrim yaitu kekeringan mengakibatkan penurunan produksi $10 \%$ dan cuaca dengan curah hujan tinggi bahkan dapat menurunkan produksi sampai 80\%. Produktivitas kopi Lampung di 
3 kabupaten berada di bawah 1 ton yaitu berkisar $0,65-0,98$ ton.ha ${ }^{-1}$ pada periode 2011-2017.

Produktivitas berfluktuasi terutama di Lampung Utara dengan standar deviasi tertinggi dari kabupaten lainnya sedangkan di Lampung Barat terjadi fluktuasi produktivitas yang paling kecil (Tabel 2). Cara budidaya yang telah menjadi kearifan lokal perlu dipelajari untuk dapat disosialisasikan di daerah lain terutama terkait adanya ekstrimitas curah hujan akibat perubahan iklim.

Tabel 2. Fluktuasi produktivitas kopi di tiga kabupaten

\begin{tabular}{lllll}
\hline No & Peubah & Lampung Barat & Tanggamus & Lampung Utara \\
\hline 1 & Nilai rerata & 0,98 & 0,79 & 0,65 \\
2 & Standar deviasi & 0,0683 & 0,0898 & 0,1512 \\
3 & Regresi & $\mathrm{y}=0,0056 \mathrm{x}+0,9422$ & $\mathrm{y}=0,0069 \mathrm{x}+0,8481$ & $\mathrm{y}=-0,0266 \mathrm{x}+0,861$ \\
4 & $\mathrm{R}^{2}$ & 0,1001 & 0,00903 & 0,5869 \\
\hline
\end{tabular}

Sumber: Analisis data

\section{Varibilitas Curah Hujan dan Produksi}

Hasil analisa data tahun 1976-2010 menunjukkan bahwa suhu udara secara umum naik antara $0,32-0,7^{\circ} \mathrm{C}$ dan terjadi pergeseran musim yaitu musim kering lebih panjang (Manik et al., 2014). Jika temperatur udara meningkat dan musim kemarau lebih panjang maka terjadi pergeseran kesesuaian lahan yaitu wilayah pegunungan yang lebih tinggi akan semakin sesuai untuk tanaman kopi (Meza, 2014), sedangkan wilayah dataran sedang akan semakin kurang sesuai dan semakin sesuai untuk tanaman yang lain sehingga terjadi kompetisi penggunaan lahan (Jassogne et al., 2013). Pada wilayah dataran rendah dan sedang, pergeseran tataguna lahan kebun kopi menjadi pertanaman lainnya telah dilaporkan Evizal et al. (2018) yaitu kebun kopi beralih menjadi kebun kakao. Hasil analisis menunjukkan bahwa rata-rata curah hujan pada dekade 2001-2010 menunjukkan peningkatan keterjadian cuaca ekstrim yaitu tingginya curah hujan pada bulan Desember dan rendahnya curah hujan pada bulan Januari-Mei. Cuaca di Propinsi Lampung mengalami bulan kering selama 5 bulan atau lebih secara periodik 3 tahun yaitu 2006, 2009, 2012, dan 2015 dan mengalami curah hujan yang tinggi 5 bulan atau lebih pada tahun 2008, 2010, 2011, 2016 dan 2017 (Gambar 2). 


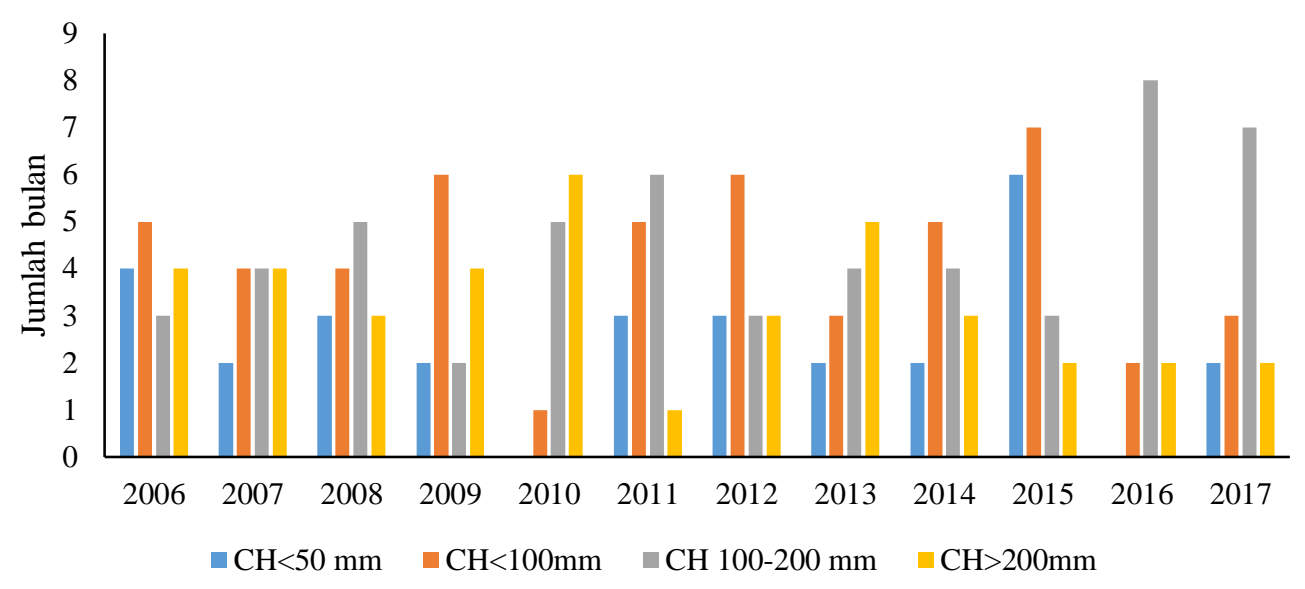

Gambar 2. Dinamika bulan kering dan basah di Lampung

Variabel hujan sebelum musim panen dapat berkorelasi positif atau negatif dengan produksi kopi dengan korelasi yang tidak selalu konsisten antara Kabupaten Lampung Barat dan Kabupaten Lampung Utara. Jumlah hari hujan tahun sebelumnya berkorelasi negatif dengan produksi. Jumlah curah hujan dan jumlah hari hujan bulan Oktober sampai Maret berkorelasi positif dengan produksi (Tabel 3).

Tabel 3. Korelasi variabel hujan terhadap produksi kopi 2011-2017

\begin{tabular}{lll}
\hline Variabel hujan tahun sebelumnya & Lampung Barat & Lampung Utara \\
\hline Curah hujan & 0,191559 & $-0,1144$ \\
Hari hujan & $-0,20338$ & $\mathbf{- 0 , 4 8 3 5 9}$ \\
Bulan kering & $-0,02711$ & 0,176286 \\
Bulan lembab & 0,186761 & 0,080115 \\
Bulan basah & $-0,08569$ & $-0,25557$ \\
Bulan sangat kering & $-0,00188$ & $\mathbf{0 , 5 2 3 7 5 3}$ \\
Curah hujan April-September & 0,096038 & $-0,16769$ \\
Hari hujan April-September & $-0,31129$ & 0,330656 \\
Curah hujan Oktober-Maret & $\mathbf{0 , 4 4 5 0 7 9}$ & $\mathbf{0 , 6 4 0 7 9 6}$ \\
Hari hujan Oktober-Maret & 0,172263 & $\mathbf{0 , 6 8 7 2 4 4}$
\end{tabular}

Keterangan: bulan kering $=\mathrm{CH}<100 \mathrm{~mm} \cdot$ bulan $^{-1}$, bulan sangat kering $=\mathrm{CH}<50 \mathrm{~mm}$.bulan ${ }^{-1}$, bulan lembab $=$ CH 100-200 mm.bulan ${ }^{-1}$, dan bulan basah $=\mathrm{CH}>200 \mathrm{~mm} \cdot$ bulan $^{-1}$.

Berbagai variabel hujan sebelum musim panen dapat berkorelasi positif atau negatif dengan produktivitas kopi juga menunjukkan perbedaan nilai korelasi antara kabupaten di wilayah pegunungan (Kabupaten Lampung Barat) dan wilayah kaki pegunungan dengan elevasi yang lebih rendah (Kabupaten Lampung Utara). Jumlah curah hujan, hari hujan, bulan lembab, curah hujan bulan April - September, curah hujan dan jumlah hari hujan bulan Oktober - Maret berkorelasi 
positif dengan produktivitas kopi di Lampung Utara, sedangkan jumlah bulan kering dan jumlah bulan sangat kering berkorelasi negatif. Di Lampung Barat, jumlah bulan kering berkorelasi positif sedangkan jumlah hari hujan seahun dan jumlah hari hujan bulan April - September berkorelasi negatif (Tabel 4).

Hasil ini menunjukkan bahwa di wilayah pegunungan, jumlah hari hujan yang tinggi berpengaruh negatif dengan produktivitas sedangkan jumlah bulan kering berpengaruh positif. Kemarau 2-3 bulan diperlukan untuk mendorong pembungaan sedangan hujan yang berlebihan akan mengakibatkan kerontokan bunga dan buah sebagaimana dilaporkan oleh Evizal et al. (2019). Sedangkan di wilayah dengan elevasi sedang (500-700 m dpl) produktivitas kopi membutuhkan curah hujan yang cukup dan produktivitas akan menurun apabila tanaman mengalami kekeringan. Dengan kata lain, tanaman kopi di dataran rendah akan lebih rentan kekeringan daripada tanaman kopi di wilayah pegunungan.

Kemarau berkepanjangan menyebabkan daun rontok hampir merata, keterjadian mati ranting meningkat, bunga mengering sebelum sempat mekar karena tidak ada hujan, putik kerdil kurang berkembang, dan buah kering menghitam sebelum pengisian biji sempurna, biji kurang berbobot. Hujan lebat berkepanjangan menyebabkan bunga sedikit, bunga membusuk, putik dan buah membusuk karena terlalu sering ditimpa hujan, buah mudah rontok. Pengaruh tersebut pada akhirnya menyebabkan penurunan hasil kopi pada saat cuaca ekstrim sehingga terjadi fluktuasi produksi kopi (Evizal et al., 2019; Wanga et al., 2015).

Tabel 4. Korelasi variabel hujan terhadap produktivitas kopi 2011-2017

\begin{tabular}{lll}
\hline Variabel hujan tahun sebelumnya & Lampung Barat & Lampung Utara \\
\hline Curah hujan & $-0,25953$ & $\mathbf{0 , 5 5 0 7 0 8}$ \\
Hari hujan & $\mathbf{- 0 , 4 6 4 9 7}$ & $\mathbf{0 , 4 9 0 8 8 2}$ \\
Bulan kering & $\mathbf{0 , 4 1 4 2 1 5}$ & $\mathbf{- 0 , 5 8 4 5 7}$ \\
Bulan lembab & $-0,13747$ & $\mathbf{0 , 4 8 1 8 3 3}$ \\
Bulan basah & $-0,39598$ & 0,378131 \\
Bulan sangat kering & 0,393215 & $\mathbf{- 0 , 6 6 3 8 8}$ \\
Curah hujan April-September & $-0,36059$ & $\mathbf{0 , 5 4 8 1 6 8}$ \\
Hari hujan April-September & $\mathbf{- 0 , 5 1 9 1 9}$ & 0,385744 \\
Curah hujan Oktober-Maret & $-0,04301$ & $\mathbf{0 , 5 3 0 2 9 5}$ \\
Hari hujan Oktober-Maret & $-0,37792$ & $\mathbf{0 , 6 7 9 6 0 4}$ \\
\hline
\end{tabular}

Keterangan: bulan kering $=\mathrm{CH}<100 \mathrm{~mm}$ bulan $^{-1}$, bulan sangat kering $=\mathrm{CH}<50 \mathrm{~mm} \cdot$ bulan $^{-1}$, bulan lembab $=$ CH 100-200 mm.bulan ${ }^{-1}$, dan bulan basah $=\mathrm{CH}>200$ mm.bulan ${ }^{-1}$.

Cheserek dan Gichimu (2012) berpendapat bahwa variabilitas iklim merupakan penyebab utama fluktuasi produksi kopi. Tantangan bagi pemuliaan tanaman adalah mencari kultivar yang 
toleran terhadap variabilitas iklim. Terkait agroteknologi pengelolaan kebun kopi, strategi adaptasi terhadap perubahan iklim antara lain melalui pengelolaan tanah dan air, perencanaan pemupukan, pengelolaan mulsa, pengendalian hama dan penyakit, dan penanaman pohon campuran sebagai sumber pendapatan selain kopi seperti dilaporkan oleh Fischersworring et al. (2015) dan Supriadi (2014).

\section{Strategi Adaptasi}

Hasil survei menunjukkan bahwa petani kopi di Lampung Barat melakukan berbagai tindakan adaptasi dengan meningkatkan pemeliharaan sehingga tanaman berproduksi tinggi meskipun mengalami ekstimitas curah hujan. Upaya pemilihan bahan tanam baik untuk batang bawah maupun bahan entres disetujui (baik setuju maupun sangat setuju) oleh $71 \%$ responden, aplikasi pupuk buatan dengan tepat disetujui $92 \%$ responden, peningkatan dosis pupuk kandang disetujui $77 \%$ responden, pemangkasan cabang yang tepat disetujui $93 \%$ responden, penanaman pohon pelindung disetujui $96 \%$ responden, pengendalian gulma yang tepat disetujui $77 \%$ responden, aplikasi insektisida yang tepat disetujui $85 \%$ responden, pembuat rorak disetujui $96 \%$ responden, namun melakukan penyiraman di musim kemarau tidak disetujui oleh $75 \%$ responden karena biaya mahal dan kesulitan memperoleh air di musim kemarau.

Tabel 5. Strategi adaptasi budidaya kopi

\begin{tabular}{lllll}
\hline No. & Strategi budidaya & $\begin{array}{l}\text { Kurang } \\
\text { setuju (\%) }\end{array}$ & $\begin{array}{l}\text { Setuju } \\
(\%)\end{array}$ & $\begin{array}{l}\text { Sangat } \\
\text { setuju (\%) }\end{array}$ \\
\hline 1. & Menanam varietas kopi yang toleran toleran & 36,8 & 37,3 & 25,9 \\
& variabilitas curah hujan dan serangan nematoda & & & \\
2. & Klonisasi (menyambung) dengan klon toleran & 21,5 & 35,7 & 42,8 \\
& variabilitas curah hujan & & & \\
3. & Memupuk kimia dengan tepat dosis, waktu, dan cara & 7,8 & 63,1 & 29,1 \\
4. & Meningkatkan dosis pupuk organik & 22,6 & 44,5 & 32,9 \\
5. & Pemangkasan cabang yang tepat & 7,2 & 56,0 & 36,8 \\
6. & Menanam pohon pelindung & 3,8 & 56,6 & 39,6 \\
7. & Pengendalian gulma yang tepat & 23,0 & 38,5 & 38,5 \\
8. & Aplikasi insektisida yang tepat & 15,4 & 76,9 & 7,7 \\
9. & Membuat rorak & 3,8 & 85,1 & 11,1 \\
10. & Melakukan penyiraman di musim kemarau & 74,7 & 18,2 & 7,1 \\
\hline
\end{tabular}

Pemupukan kimia diyakini petani sangat penting untuk mendorong pertumbuhan tanaman sehingga toleran terhadap variabilitas curah hujan. Dalam FGD terungkap bahwa pemupukan dilakukan pada bulan September (awal musim hujan) dan Mei (akhir musim hujan), namun saat 
pemupukan yang tepat harus melihat pertumbuhan bunga dan buah. Pada bulan Mei, ketika buah pada dompol atas mulai merah dilakukan pemupukan dengan SP 36, Phonska dan Urea yang fungsinya untuk memperpanjang ranting untuk pembungaan setelah panen yaitu untuk buah musim berikutnya. Dari bulan Juli - September pembungaan akan terjadi berturut-turut sebanyak 3 kali. Pada pertengahan bulan September, pembungaan pertama sudah menjadi putik sebesar merica (fase mata yuyu), kembang pembungaan terakhir mulai rontok, dilakukan pemupukan kedua yang fungsinya untuk menyediakan hara bagi pertumbuhan biji kopi sehingga putik dan buah kopi berhasil tumbuh dan tidak mudah rontok kendatipun banyak turun hujan atau kurang hujan. Kalau tidak dipupuk atau unsur hara kurang tersedia, pembuahan banyak yang gagal, baik rontok, putik tidak berkembang menjadi buah, buah lebih kecil atau bobot biji lebih ringan. Keluarnya bunga setiap tahun pasti banyak tetapi belum tentu menjadi buah sehingga menghasilkan buah yang banyak. Hasil kopi berfluktuasi satu tahun berbuah lebat diikuti musim berbuah sedikit atau turunnya drastis misalnya tinggal 30\% dari musim lebat. Sebetulnya kopi dapat berbuah dengan hasil tetap tinggi, jika pemeliharaan terutama pemupukan dilakukan dengan tepat.

Secara tradisional petani menanam pohon pelindung teknis di perkebunan kopi terutama pohon gamal (Evizal et al., 2016). Pohon ini mempunyai fungsi lain yaitu daun dan rantingnya dipangkas sebagai pakan kambing, dan di bawah pohonnya ditanam lada sehingga akan merambat naik ke pohon gamal. Karena sering dipangkas, maka pohon gamal dipertahankan agak rendah (sektar $2 \mathrm{~m}$ ) sehingga tanaman lada dipertahankan agak pendek dengan cabang buah yang lebat. Dengan jumlah pohon lada 100-200 pohon dpat menghsilkan 1-2 kuintal lada kering.

\section{Klonisasi Kopi}

Klonisasi kopi dengan menanam batang bawah yang toleran terhadap lingkungan yang kurang menguntungkan dan menyambungnya dengan klon lokal robusta yang unggul merupakan etno-agronomi yang khas yang dipraktekkan petani kopi di Lampung Barat untuk memperoleh produktivitas kopi yang tinggi kendatipun menghadapi curah hujan yang tinggi maupun rendah. Hasil FGD menunjukkan bahwa sebagian petani memilih kopi lokal Robusta varietas Bakir dan kopi Leberika varietas Robinson untuk disemai sebagai bibit batang bawah sebagaimana telah dilaporkan Evizal (2013) karena lebih toleran terhadap kekeringan dan tanah yang kurang subur. Kopi Bakir setelah berbuah lebat pertama selanjutnya akan turun hasilnya sehingga dilakukan klonisasi dengan cara penyambungan. Kopi Robinson citarasanya kurang disukai dan tidak diterima pasar kopi Robusta sehingga setelah berbuah dilakukan penyambungan dengan kopi Robusta.

Klon batang atas yang disambungkan sangat penting dalam menentukan produktivitas dan toleransi terhadap variabitas iklim (Evizal et al, 2019). Hasil FGD mengungkapkan bahwa petani aktif mengamati, mengintroduksi, dan menyeleksi secara mandiri klon kopi yang dapat beradaptasi dengan lingkungan lokal dan berbuah lebat. Di Lampung Barat petani mengenal dan menggunakan berbagai klon kopi Robusta untuk bahan entres penyambungan kopi di kebunnya sebagaimana telah 
dilaporkan oleh Evizal et al. (2015). Petani mengembangkan kebun kopi poliklonal dengan 2-3 klon utama bahkan memiliki 2-3 klon lainnya sebagai ujicoba untuk diamati. Ada 4 klon kopi unggul lokal yang berasal dari sekitar Kecamatan Sumberjaya yang telah dilepas oleh Kementerian Pertanian yaitu: (1) klon Korolla 1 yang nama lokalnya Tugu Kuning dilepas berdasarkan Kepmentan RI No 35/KPTS/KB.020/2/2019, (2) klon Korolla 2 yang nama lokalnya Tugu Hijau dilepas berdasarkan Kepmentan RI No 36/KPTS/KB.020/2/2019, (3) klon Korolla 3 yang nama lokalnya Lengkong dilepas berdasarkan Kepmentan RI No 37/KPTS/KB.020/2/2019, dan klon Korolla 4 yang nama lokalnya Bodong Jaya dilepas berdasarkan Kepmentan RI No 38/KPTS/KB.020/2/2019.

Apabila kondisi optimum, maka akan dapat dicapai potensi hasil 1,39-3,34 ton/ha biji kering namun apabila kondisi curah hujan yang ekstrim maka produktivitas anjlok mencapai separuhnya (0,8-1,5 ton/ha) untuk klon yang kurang toleran variabilitas iklim dan produktivitas klon yang tidak toleran anjlok tinggal sepertiganya yaitu menjadi $<0,8$ ton/ha sebagaimana telah dilaporkan Evizal et al. (2019). Namun demikian dari FGD dan pengamatan di lapangan terungkap bahwa terdapat klon lokal yang toleran terhadap variabilitas iklim namun perlu mendapat pemeliharaan yang optimal terutama pemupukan yang tepat. Klon unggul lokal ini dapat ditemukan di Lampung Barat seperti di Kecamatan Sekincau.

\section{KESIMPULAN}

Areal kebun kopi di Lampung Barat dalam satu dekade terakhir turun 0,64\% per tahun namun produktivitas meningkat $1,42 \%$ per tahun. Di Lampung Barat yang merupakan wilayah pegunungan, jumlah hari hujan yang tinggi berkorelasi negatif dengan produktivitas sedangkan jumlah bulan kering berkorelasi positif. Sedangkan di Lampung Utara yang merupakan wilayah dengan elevasi sedang, produktivitas kopi berkorelasi dengan curah hujan yang cukup dan produktivitas berkorelasi negatif dengan jumlah bulan kering tahun sebelumnya. Petani kopi di Lampung Barat berpersepsi bahwa perlunya berbagai tindakan adaptasi dengan meningkatkan pemeliharaan sehingga tanaman berproduksi tinggi meskipun mengalami ekstrimitas curah hujan yaitu: (a) pemilihan bahan tanam unggul baik untuk batang bawah maupun bahan entres, aplikasi pupuk buatan dengan tepat, peningkatan dosis pupuk kandang, pemangkasan cabang yang tepat, penanaman pohon pelindung, pengendalian gulma yang tepat, aplikasi insektisida yang tepat, dan pembuat rorak. Grafting pohon kopi dewasa menggunakan klon lokal robusta yang unggul merupakan etno-agronomi yang khas yang dipraktekkan petani kopi di Lampung Barat untuk memperoleh produktivitas kopi yang tinggi kendatipun menghadapi variabilitas curah hujan.

\section{UCAPAN TERIMA KASIH}

Ucapan terima kasih disampaikan kepada LPPM Universitas Lampung atas bantuan dana Penelitian Unggulan Tahun 2018. 


\section{DAFTAR PUSTAKA}

Alemu, A. \& Dufera, E. (2017). Climate smart coffee (Coffea arabica) production. American Journal of Data Mining and Knowledge Discovery, 2(2), 62-68.

Baca. M., Laderach, P., Haggar, J., Schroth, G. \& Ovalle, O. (2014). An integrated framework for assessing vulnerability to climate change and developing adaptation strategies for coffee growing families in Mesoamerica. Plos One, 9(2), e88463. doi:10.1371/journal. pone.0088463.

Cheserek, J.J. \& Gichimu, B.M. (2012). Drought and heat tolerance in coffee: a review. International Research Journal of Agricultural Science and Soil Science, 2(12), 498-501.

Davis, A.P., Gole, T.D., Baena, S., \& Moat, J. (2012). The impact of climate change on indigenous Arabica coffee (Coffea arabica): Predicting future trends and identifying priorities. Plos One, 7(11), 1-13.

Evizal, R., Tohari, Prijambada, I.D., Widada, J., Prasmatiwi, F.E., \& Afandi. (2010). Pengaruh tipe agroekosistem terhadap produktivitas dan keberlanjutan usahatani kopi. Jurnal Agrotropika, 15(1), 17-22.

Evizal, R. (2013). Etno-agronomi Pengelolaan Perkebunan Kopi di Sumberjaya Kabupaten Lampung Barat. Agrotrop, 3(2), 1-12.

Evizal, R., Sugiatno, \& Prasmatiwi, F.E. (2015). Ragam kultivar kopi di Lampung. Agrotrop, 5(1), 80-88.

Evizal, R., Sugiatno, Prasmatiwi, F.E., \& Nurmayasari, I. (2016). Shade tree species diversity and coffee productivity in Sumberjaya, West Lampung, Indonesia. Biodiversitas, Journal of Biological Diversity. 7(1), 234-240.

Evizal, R., Prasmatiwi, F.E., Pasaribu, M.C., Ivayani, Wibowo, L., Rahmawati, W., \& Karyanto, A. (2018). Competitive and sustainable production of cocoa in Tanggamus, Lampung Province, Indonesia. Proc. ISAE Lampung International Seminar. Bandar Lampung. Pp. 705-712.

Evizal, R., Prasmatiwi, F.E., Widagdo, S. \& Novpriansyah, H. (2019). Adaptasi budidaya kopi di Lampung pada perubahan iklim. Pros. Seminar dan Lokakarya Nasional FKPTPI 2018. Pp. 1421.

Fischersworring, B., Lonsdate, K, Schmidt, G., Ochoa, M., Linne, G., Opitz, M., Pringle, P., Walton, P., Baker, P.S., \& Ruiz, P. (2015). Climate change adaptation in coffee production. Coffee and Climate, a step by step guide to supporting coffee farmers in adapting to climate change. www.coffeeandclimate.org.

Jassogne, L., Laderach, P. \& van Asten, P. (2013). The impact of climate change on coffee in Uganda. Oxfam Research Reports.

Manik, T.K., Rosadi, B. \& Nurhayati, E. (2014). Mengkaji dampak perubahan iklim terhadap distribusi curah hujan lokal di Propinsi Lampung. Forum Geo, 28(1), 73-86.

Meza, L.E.R. (2014). Adaptive capacity of small-scale coffee farmers to climate change impacts in the Soconusco region of Chiapas, Mexico. Climate and Development, 7(2), 100-109.

Ovalle-Rivera. O., Laderach, P., Bunn, C., Obersteiner, M., \& Schroth, G. (2015). Projected shifts in Coffea arabica suitability among major global producing regions due to climate change. Plos 
One 10(4):e0124155. doi:10.1371/journal. pone.0124155.

Panhuysen, S. \& Pierrot, J. (2014). Coffee Barometer 2014. Drukkerij Mostert \& Van Onderen. Leiden.

Reidsma, P., Ewert, F., Lansink, A.O., \& Leemans, R. (2010). Adaptation to climate change and climate variability in European Agriculture: The importance of farm level responses. Europen Journal of Agronomy, 32, 91-102.

Syakir, M. \& Surmaini, E. (2017). Perubahan iklim dalam konteks sistem produksi dan pengembangan kopi di Indonesia. Jurnal Litbang Pertanian, 36(2), 77-90.

Supriadi, H. (2014). Budidaya tanaman kopi untuk adaptasi dan mitigasi perubahan iklim. Perspektif, $13(1), 35-52$.

Wanga, N., Jassogne, L., van Asten, P.J.A., Mukasa, D., Wanyama, I., Kagezi, G., \& Giller K.E. (2015). Evaluating coffee yield gaps and important biotic, abiotic, and management factors limiting coffee production in Uganda. European Journal of Agronomy, 63, 1-11. 